\title{
Zakopiańskie Warsztaty
}

\section{Wzorcowe -}

działalność wytwórcza

pierwszej na Podhalu spółdzielni artystycznej*

DOI: https://doi.org/10.21697/an.9378

JULIA MOHELICKA

ZAKOPANE

\section{CEL I ZAKRES ARTYKUŁU}

Niniejszy artykuł przedstawia historię początku, rozkwitu i upadku Zakopiańskich Warsztatów Wzorcowych (dalej jako ZWW), działających w latach 1948-2007. ZWW, jak większość zakładów produkcji rzemieślniczej i artystycznej, zostały włączone do Cepelii (Centrali Przemysłu Ludowego i Artystycznego) w 1949 r. Źródłem wiedzy, zwłaszcza na temat podstawowych danych dotyczących spółdzielni ZWW, wielkości jej produkcji, zatrudnienia, sprzedaży krajowej i wielkości eksportu, była przede wszystkim praca Romana Gmurczyka Organizacja cepeliowska w latach 1949-2014. Faktyi ludzie'. Poza tym opracowaniem

\footnotetext{
* Niniejszy tekst ma charakter komunikatu opartego o archiwalne źródła znajdujące się w zbiorach prywatnych, a także o świadectwa świadków - historię mówioną, relacje uczestników wydarzeń, twórców, artystów i pracowników spółdzielni Zakopiańskie Warsztaty Wzorcowe. W tym sensie tekst ten ma za zadanie wskazać podstawowe kierunki badań i kwerend źródłowych, poza którymi znajdują się także zasoby Archiwum Narodowego w Krakowie:Zakopiańskie Warsztaty Wzorcowe Spółdzielni Pracy Rękodzieła Ludowego i Artystycznego w Zakopanem, przechowywane i udostępniane w Ekspozyturze w Spytkowicach (nr zespołu 32/750) oraz w Oddziale w Nowym Sączu (nr zespołu 31/1121).
}

niewiele jest materiałów drukowanych na temat działalności spółdzielni. Sprowadzają się one do kilkunastu wycinków prasowych z lat 60. i 70. XX w., archiwizowanych przez Miejską Bibliotekę Publiczną w Zakopanem. Są to jednak na ogół krótkie notatki mówiące o sukcesach ZWW, udziale artystów w konkursach i przeglądach, o sympozjach organizowanych w Zakopanem na temat sztuki ludowej.

W niniejszym komunikacie wykorzystane zostały również zachowane katalogi wystaw takie jak: Artyści plastycy-projektanci Zakopiańskich Warsztatów Wzorcowych w XXX-lecie działalności i i 25-lecie Zakopiańskich Warsztatów Wzorcowych ${ }^{3}$, w których brała udział Spółdzielnia ZWW, bądź indywidualni artyści w tych warsztatach zatrudnieni. Nieocenioną pomocą w uzyskaniu informacji na temat działalności ZWW było archiwum prywatne oraz przekazy ustne Tomasza Knasta, historyka sztuki, pracującego w ZWW przez 30 lat, w tym

1 R. Gmurczyk, Organizacja cepeliowska w latach 1949-2014. Fakty i ludzie, Warszawa 2014.

2 Artyści plastycy - projektanci Zakopiańskich Warsztatów Wzorcowych w XXX-lecie działalności [katalog wystawy], Nowy Targ 1977.

325-lecie Zakopiańskich Warsztatów Wzorcowych [katalog wystawy], Zakopane 1973. 
w ciągu 25 lat pełniącego funkcję kierownika nadzoru artystycznego. Brak jest naukowego, monograficznego opracowania tematu działalności ZWW. Autorka niniejszego artykułu - wówczas studentka kierunku Gospodarka i Administracja Publiczna na Uniwersytecie Ekonomicznym w Krakowie, podjęła tę problematykę w 2018 r. podczas badań do pracy magisterskiej pt. Zakopiańskie Warsztaty Wzorcowe jako przykład spótdzielczości w Polsce $e^{4}$. Praca ta w części empirycznej podaje szereg przyczyn, dlaczego doskonale rozwijającemu się przedsiębiorstwu, wpisanemu w klimat artystyczny Zakopanego i Podhala, zatrudniającemu jako projektantów najlepszych artystów plastyków, przez wiele lat odpowiadającemu na zapotrzebowania odbiorców, osiągającemu sukcesy eksportowe, nie udało się przetrwać i upadło ono po sześćdziesięciu latach działalności. Autorka wskazała wiele przyczyn ekonomicznych, oraz zwróciła uwagę, że oprócz nich sporą rolę odegrały prawdopodobnie zmiany pokoleniowe młode pokolenie bagatelizuje, a nawet odrzuca sztukę ludową, moda na wyroby ludowe w Polsce, jak zresztą w całej Europie, znacznie się zmniejszyła, co spowodowało spadek sprzedaży, a zwłaszcza eksportu.

W artykule zostanie przedstawiony zarys historii, najważniejsze kierunki działalności ZWW oraz organizacja pracy rękodzielników, twórców. Praca ta może stanowić punkt wyjścia do dalszych, pogłębionych badań nad przytoczonym tematem, zwłaszcza, że zarówno organizacja, jak i skupieni wokół niej ludzie warci są bardziej wyczerpującego opracowania.

4 J. Mohelicka,Zakopiańskie Warsztaty Wzorcowe Cepelia jako przykład spółdzielczości w Polsce, praca magisterska napisana w Katedrze Gospodarki Publicznej, pod kierunkiem dr. hab. Łukasza Mamicy, prof. UEK, Uniwersytet Ekonomiczny w Krakowie, 2018.

\section{POWSTANIE I DZIALALNOŚĆ WYTWÓRCZA ZAKOPIAŃSKICH WARSZTATÓW WZORCOWYCH}

Kultura ludowa rozwijała się na Podhalu od początków osadnictwa. W drugiej połowie XIX w. znalazła się pod wpływem kultury coraz liczniej przybywających tu w celach leczniczych i turystycznych gości. Jeszcze później zetknęła się ze środowiskiem elit artystycznych, których wielu przedstawicieli osiedliło się tu na stałe. Od końca XIX w. możemy więc mówić o wzajemnym przenikaniu się tych dwóch kultur - rodzimej i napływowej, przy czym należy podkreślić, że kultura góralska fascynowała przybyszów z zewnątrz. Odznaczając się dużą oryginalnością, budziła ich żywe zainteresowanie.

To zainteresowanie przyczyniło się do powstania na Podhalu przemysłu pamiątkarskiego. Pamiątkarstwo zakopiańskie było zagadnieniem nie tylko artystycznym, lecz także gospodarczym. Stało się źródłem utrzymania wielu zakopiańskich rodzin. Miejscowi cieśle, rzeźbiarze, tkacze produkowali pamiątki dla przyjezdnych gości. Powstawały rzeźbione kasetki, talerze z szarotkami, popielniczki w kształcie kierpców, drewniane osty. Przedmioty te nosiły często silne wpływy obce, głównie tyrolskie. Działające w Zakopanem szkoły artystyczne zatrudniały też nauczycieli cudzoziemców, którzy przeszczepiali na grunt podhalański wzory szwajcarskie i wiedeńskie. Zwracali na to uwagę światli obywatele Zakopanego, przede wszystkim Juliusz Zborowski, który w referacie wygłoszonym 9 marca 1929 r. ${ }^{5}$, mówiąc o konieczności ochrony swojszczyzny na Podhalu, podkreślał zwłaszcza szczególną rolę, jaką odgrywa tu sztuka ludowa. Mówił, że należy

\footnotetext{
5 J. Zborowski, Ochrona swojszczyzny, przemysł ludowy na Podhalu, postulaty kulturalne ludności miejscowej i przyjezdnych, w: tenże, Pisma podhalańskie, t. 2, Kraków 1972, s. 380-390 (pierwodruk: „Ziemia”, r. 14, 1929, nr 12, s. 196-201).
} 
zaopiekować się resztkami przemysłu artystycznego i ludowego, pozostałymi z dawnej epoki na Podhalu. „Należy przede wszystkim przeprowadzić rejestrację, co jeszcze w tym kierunku, w jakich ilościach i w jakich wartościach reprezentuje Podhale. [...] Drugi postulat, to zapewnienie zbytu ludowym wyrobom. Sam jarmark i domokrążstwo nie wystarcza. Niejedna rzecz piękna lub praktyczna znajdzie zbyt i poza Podhalem. Toteż po rejestracji należy pomyśleć o dostarczeniu tych towarów czy to przybyszom sezonowym, czy też na eksport do miejskich ośrodków poza nasz region. [...] Oprócz tradycyjnego zdobnictwa i przemysłu ludowego powstał na Podhalu, a szczególnie w Zakopanem, nowy rodzaj przemysłu artystycznego, oparty o szkolnictwo i o importowane wytwórnie. [...] Przemysł ten przeszedł już w poważnej mierze w ręce góralskiego pracownika i staje się jego źródłem zarobkowania. [...] Prywatnej inicjatywie, zasługującej naprawdę na poparcie, należy pomóc w postaci kredytu, subwencji lub pożyczek. Co się zaś tyczy przemysłu pochodnego ze szkół, należy tak w interesie jakości wyrobów, jak i zarobkującego wytwórcy, zakładać kooperatywy byłych uczniów szkół, kooperatywy samodzielne, ale związane ze szkołą i znajdujące się pod jej kierunkiem artystycznym. I ta sprawa wymaga poparcia finansowego, przede wszystkim kredytu czy pożyczek, które mogłyby być nawet wyrównane gotowym towarem".

Juliusz Zborowski powrócił do tego tematu niedługo po zakończeniu II wojny światowej. W kolejnym referacie ${ }^{7}$, wygłoszonym 6 grudnia 1947 r., mówił, jak ogromne znaczenie dla Podhala ma przemysł ludowy, pamiątkarski i artystyczny

6 Tamże, s. 384, 385.

7 J. Zborowski, W sprawie kulturalnych potrzeb Zakopanego, w: tenże, Pisma podhalańskie, t. 2, Kraków 1972, s. 397-398.
- i jako zarobek dla wielkiej liczby górali, i jako propaganda Podhala. Apelował, aby wiązać dawne tradycje, dawne wzory z nowymi potrzebami. „Nie jest to łatwe, bo sztuka ludowa dawna zamiera z powodu zmiany warunków chłopskiego życia. Gdzie jeszcze są resztki dawnej góralskiej wytwórczości, należy je otoczyć opieką i podtrzymywać. [...] Natomiast nowoczesny przemysł artystyczny i pamiątkarski trzeba zorganizować. Chałupnikom trzeba dostarczać surowców, poddawać opieranie się na dobrych wzorach, tworzyć wzorcownie oraz organizować zbyt i eksport. Powstała już w Zakopanem farbiarnia Samopomocy Chłopskiej, konieczne jest założenie suszarni. Na Podhalu istnieje przemysł drzewny, kilimkarski, wełniarski, metalowy, ceramiczny, skórzany. Eksport, jak i sprzedaż na miejscu, jest poważny ilościowo; idzie o to, aby i jakościowo mógł się podnieść w zaniedbanych dotąd gałęziach".

28 grudnia 1947 r. powołano do życia spółdzielnię, która stała się zalążkiem późniejszych Zakopiańskich Warsztatów Wzorcowych, zarejestrowanych w Sądzie Okręgowym w Nowym Sączu w dn. 19 lutego 1948 r.9 Spółdzielnia założona została przez 24 członków, z inicjatywy grupy ludzi nauki i kultury, utalentowanych artystów plastyków i twórców ludowych. Założycielami spółdzielni byli: dyrektor Muzeum Tatrzańskiego Juliusz Zborowski, prof. Wydziału Architektury Politechniki Krakowskiej Witold Dalbor, plastycy - Maria ŁomnickaBujakowa, Krystyna Szczepanowska-Miklaszewska, Andrzej Gałek, twórcy ludowi Józef Bigos, Andrzej Kubin-Opacian i inni. Ideą założycieli było zerwanie z tandetą pamiątkarstwa zakopiańskiego i „tyrolszczyzną”,

8 Tamże, s. 397-398.

9 Pod nazwą: Zakopiańskie Warsztaty Wzorcowe Spółdzielni Pracy Rękodzieła Ludowego i Artystycznego w Zakopanem, Nr RS.IV-71, za: https://szukajwarchiwach.pl/29/3560/0\#tabZespol [dostęp 10 I 2021]. 
oparcie się na najlepszych wzorach i tradycji wytwórczych Podhala ${ }^{10}$.

Przyjęto statut i powołano Radę Nadzorczą, do której obok Witolda Dalbora weszli Janina Alchimowicz i Kazimierz Fajkosz. Rada Nadzorcza wybrała zarząd, w skład którego wchodził też Juliusz Zborowski. Ustalono dwa główne cele spółdzielni: zatrudnienie zarobkowe jej członków i ich rodzin przy wytwarzaniu wyrobów przemysłu ludowego oraz produkowanie i wprowadzanie w obrót jedynie przedmiotów pełnowartościowych artystycznie, noszących znamiona regionalizmu podhalańskiego.

Działalność zakopiańskiej spółdzielni rozpoczęła się od skupu wyrobów regionalnych - galanterii drzewnej, wyrobów ze skóry i metalu, ceramiki oraz filcowych pantofli, kierpców i serdaków. Potem zaczęto organizować wytwórczość chałupniczą: spółdzielnia zamawiała u wytwórców określone wyroby, zaopatrywała ich także w surowce. W $1948 \mathrm{r}$. zatrudniała łącznie 145 osób. Wyroby sprzedawane były w dwóch sklepach w Zakopanem, przy ul. Krupówki i przy ul. Kościeliskiej ${ }^{11}$.

Dzięki wydatnej i fachowej pomocy Juliusza Zborowskiego opracowano nowe wzory, opierając się na zabytkowych przedmiotach podhalańskich. Podstawową ofertę handlową stanowiły liczne wzory, modele z drewna, metalu, gliny. Były to m.in. redykałki, obrazy na szkle, lichtarze, klamry, łyżki. O walorach artystycznych tych modeli decydowało Biuro Nadzoru i Estetyki przy Ministerstwie Przemysłu i Handlu. Instytut Przemysłu Ludowego, powstałe w 1946 r., było wielką pomocą

10 R. Gmurczyk, dz. cyt., s. 180-184, M. Sarkowicz, Zakopiańskie Warsztaty Wzorcowe, „Podtatrze”, 1978, zima, s. 18-23.

11 Przytaczane informacje i dane faktograficzne, jeśli nie zaznaczono inaczej, pochodzą z zasobów prywatnych oraz z archiwum i przekazów ustnych Tomasza Knasta. w realizacji założeń zakopiańskiej spółdzielni. Dostawcą surowców i odbiorcą wyrobów była Centralna Spółdzielnia Pracy, której działalność nastawiona była na handel przedmiotami powszechnego użytku. W związku z tym, że sprzedaż przedmiotów artystycznych nie przynosiła dostatecznych dochodów, aby utrzymać spółdzielnię podjęto produkcję przedmiotów użytkowych, luźno związanych z pamiątkarstwem. Były to góralskie pantofle z sukna i filcu, pantofle na sznurkowych podeszwach, swetry, szale. 1 sierpnia 1949 r. Zakopiańskie Warsztaty Wzorcowe zostały włączone do powołanej tydzień wcześniej SpółdzielczoPaństwowej Centrali Przemysłu Ludowego i Artystycznego, która przejmowała większość zakładów produkcji artystycznej i rzemieślniczej w kraju. W tym też czasie ZWW połączyły się z Wydziałem Przemysłu Artystycznego, utworzonym w 1946 r. przy Gminnej Spółdzielni „Samopomoc Chłopska”. Oficjalne połączenie odbyło się 31 grudnia 1949 r. Spółdzielnia ZWW nabyła od Gminnej Spółdzielni zapasy surowca, urządzenia i, na zasadzie ciągłości zatrudnienia, wszystkich pracowników. W następnych latach ZWW przejęły kilka innych, małych zakładów Spółdzielnię Garbarsko-Futrzarską, Spółdzielnię Szewską „Sport”, Spółdzielnię Tatrzańską w Poroninie, Spółdzielnię „Czerwone Wierchy", Wytwórnię Galanterii Drzewnej.

W 1950 r. kierownictwo Spółdzielni objął Mieczysław Ciecióra, wprowadzając nową organizację pracy i poszerzając zakres działania Spółdzielni. W 1951 r. Spółdzielnia ZWW połączyła się z Wydziałem Przemysłu Artystycznego Gminnej Spółdzielni „Samopomoc Chłopska", w której wykonywano kilimy i tkaniny dekoracyjne, a w 1952 r. przejęła Tatrzańską Spółdzielnię Przemysłu Ludowego i Artystycznego w Poroninie, skupiającą się na wytwórczości stolarskiej. To przyczyniło się do dynamicznego rozwoju tkactwa artystycznego i meblarstwa. 
W 1954 r. zakład krawiecki działający w ZWW w ramach reorganizacji został przekazany Robotniczej Spółdzielni Krawców w Zakopanem, a zakład obuwniczy - Zakopiańskiej Spółdzielni „Giewont”.

Ostatecznie ta wielobranżowa spółdzielnia ukształtowała się w 1954 r., choć nadal nie była organizmem spójnym. Poszczególne działy rozproszone były w różnych punktach Zakopanego. Wkrótce kierownictwo Spółdzielni zaczęło planować utworzenie jednego dużego zakładu wytwórczego. W 1957 r. rozpoczęto budowę nowego zakładu przy ul. Szymony, którą zakończono w 1962. W nowym obiekcie znalazły się hale produkcyjne (tkalnie, stolarnie), wzorcownia, pomieszczenia biurowe, magazyny, obiekty zaplecza produkcyjnego. Uruchomiono też garbarnię i oddział szycia kożuchów. Jednak w dalszym ciągu zasadnicza część wytwórczości Spółdzielni wykonywana była w systemie pracy chałupniczej. W 1963 r. członkami spółdzielni było już 545 osób.

Niezwykle dynamiczny rozwój wzornictwa podhalańskiego spowodował, że już w drugiej połowie lat pięćdziesiątych Spółdzielnia ZWW rozpoczęła eksport kilimów, gobelinów, sumaków i innych tkanin artystycznych, a następnie galanterii drewnianej, głównie kaset oraz stylizowanych mebli z litego drewna, m.in. według projektów artysty plastyka Józefa Kulona.

Pierwszym odbiorcą wyrobów Spółdzielni była Republika Federalna Niemiec, potem Stany Zjednoczone, Holandia, Belgia, Anglia. W końcu lat 70. Spółdzielnia ZWW eksportowała prawie 60\% wytwarzanych wyrobów. Branżowa struktura wytwórczości była następująca: $25 \%$ stanowiły wyroby tkackie i hafciarskie, 15\% stanowiły wyroby z drewna, meble i galanteria drewniana, 60\% wyroby ze skóry - kożuchy, futrzaki, różnorodna galanteria skórzana.

O bogactwie wzorniczym świadczy

fakt, że w 1973 r. w bieżącej produkcji wyrobów tkacko-hafciarskich było ponad 500 wzorów i corocznie ich przybywało. Podobna sytuacja była w branży drewnianej i skórzanej - każdego roku powstawały dziesiątki wzorów inspirowanych motywami podhalańskimi. W $1973 \mathrm{r}$. w zakładzie zwartym pracowały 332 osoby, a w systemie pracy nakładczej - 816 chałupników. Była to największa liczba zatrudnionych w całej historii działalności ZWW. Poza tym Spółdzielnia prowadziła skup wyrobów regionalnych od indywidualnych wytwórców. W kolejnych etapach rozwoju ZWW zmieniały się formy ich organizacji, także częściowo profil wytwórczości, niezmienione pozostały jednak zasadnicze cele działania określone już w pierwszych działaniach statutowych. Łączyły one założenia artystyczne z programem gospodarczym i socjalnym zmierzającym do przyspieszenia ogólnego rozwoju regionu. Nawiązując do tradycji sztuki ludowej Podhala w całym bogactwie i różnorodności jej form, Spółdzielnia ZWW podjęła wytwórczość w zakresie sztuki użytkowej, rzemiosła artystycznego i pamiątkarstwa. Starano się od początku rozwijać gałęzie sztuki ludowej, żywej jeszcze w regionie, a w projektowaniu przedmiotów inspirowanych sztuką ludową adaptować charakterystyczne techniki i tworzywa, unikając kopiowania. Ze spółdzielnią współpracowali wybitni projektanci, proponujący własną sztukę i rękodzieło, kontynuujący tradycję sztuki i rzemiosła międzywojennego. Po II wojnie światowej projektanci i artyści plastycy właśnie w Zakopanem znaleźli klimat sprzyjający rozwojowi idei dobrego wzornictwa, rzemiosła artystycznego i sztuki użytkowej. W ZWW twórczo przestrzegano obowiązujących kanonów dobrego wzornictwa, czyli łączenia projektu, naturalnych, ręcznie przygotowanych surowców i ręcznego wykonania. Dobre efekty dawała stała, codzienna praca artysty plastyka z wykonawcą.

Twórcy (tkaczki, rzeźbiarze itp.) pracowali w dwóch systemach - w zakładzie 


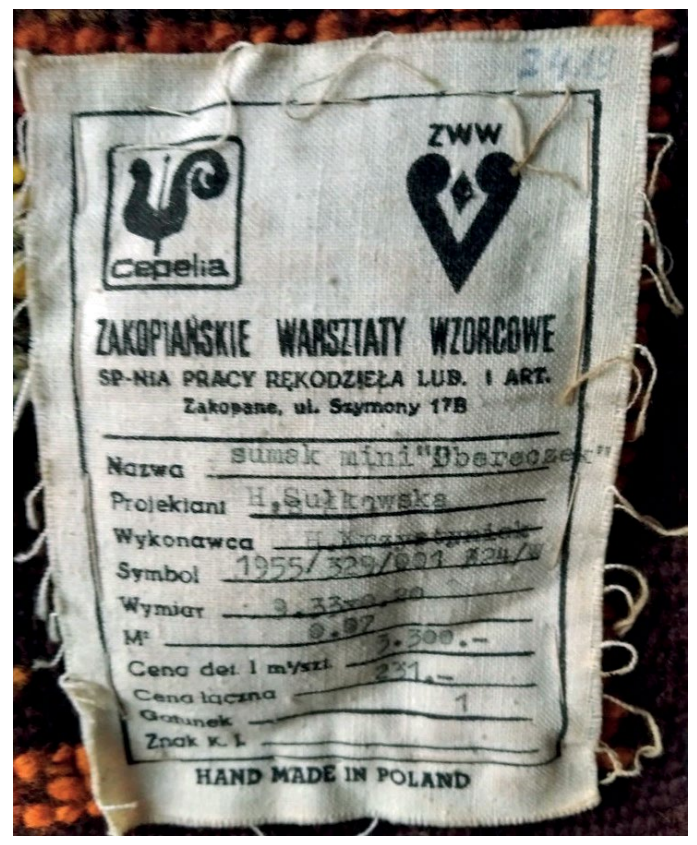

1. Oryginalna metka ZWW na gobelinie. Fot.https://a.allegroimg.com/original/1efdgc/ fab62fod405f937b13b3fc6a1596 [dostęp 2 IX 2021].

$\Delta$

pracy lub w domach. W zakładzie pracy materiały i narzędzia były ogólnodostępne. Zatrudniani pracownicy wykonywali przedmioty według wzoru, zgodnie z harmonogramem prac, w konkretnych godzinach pracy. Nakładcy pracujący poza ZWW w domach pracowali na materiałach otrzymanych ze spółdzielni. Były to przykładowo wykroje skóry, narzędzia, inne materiały w zależności od wykonywanych przedmiotów. Nakładcy zdawali w ZWW gotowe produkty, które po stwierdzeniu zgodności z projektem były rozliczane. Ten rodzaj pracy był odtwórczy. Prowadzono także skup produktów od niezależnych twórców. Takich, którzy swoje wyroby sprzedawali pod własnym nazwiskiem. Przykładem jest wybitny malarz Zdzisław Walczak (19262001), urodzony w Zakopanem. Zajmował się zdobnictwem w drewnie oraz malarstwem na szkle, był laureatem m.in. Nagrody Artystycznej dla Twórców Ludowych im. Jana Płocka oraz Nagrody im. Oskara Kolberga. Prace Zdzisława Walczaka znajdują się w zbiorach muzeów etnograficznych: w Toruniu, Warszawie, Łodzi, Krakowie oraz w Muzeum Tatrzańskim w Zakopanem i Muzeum Śląskim w Katowicach, a także

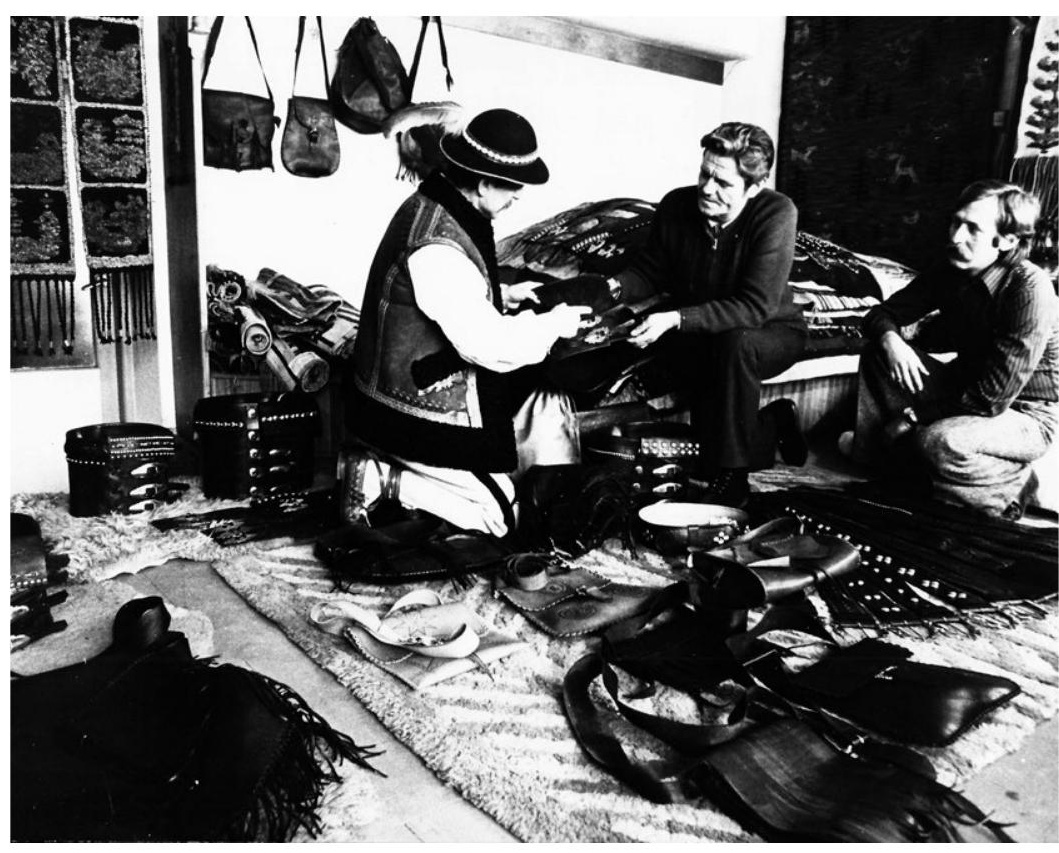

2. Wzorcownia ZWW, 1985 r. Od prawej: Tomasz Knast (kierownik nadzoru artystycznego), Mieczysław Rams (wykonawca pasów bacowskich i toreb), Jerzy Stopka (kierownik zespołu regionalnego Holny przy ZWW). Fot. W. Werner

w byłej pracowni malarza. Około dwóch tysięcy obrazów znajduje się u prywatnych właścicieli, w kraju i za granicą ${ }^{12}$.

Dzieła uznanych artystów, jak wspomniany Zdzisław Walczak, nie podlegały żadnym wytycznym. Natomiast w innych przypadkach wszelkie wzory wymagały akceptacji komisji artystycznej. Przy wykonywaniu masowych wyrobów, takich jak kasetki drewniane, torby, paski skórzane, odbioru dokonywały służby kontroli jakości wraz z kierownictwem artystycznym, czyli z projektantami (il. 1-2).

Wysoki poziom wzornictwa ZWW zawdzięczały gronu artystów plastyków, długoletnich etatowych pracowników Spółdzielni. Wymienić tu należy przede wszystkim artystkę tkaczkę Krystynę Szczepanowską-Miklaszewską (1912-1998), artystkę tkaczkę i hafciarkę Marię Bujakową (19011985) oraz artystki tkaczki: Aleksandrę Michalak-Lewińską, Helenę SułkowskąPawlik, Celinę Kamińską-Kowalewską,

12 https://www.zakopane.pl/strefa-turystyczna/ kultura/zakopianskie-centrum-kultury/czerwony-dwor/malarstwo-na-szkle-zakopianskich-tworcow/ zdzislaw-walczak [dostęp 10 XII 2020]. 
Ewę Januszkowską, Ewę Fortunę, Martę Gąsienicę-Szostak, artystę tkacza Marka Kossowskiego, Halinę Piekacz - artystkę hafciarkę, Hannę Kowalewską-Komorek artystkę projektantkę odzieży i galanterii skórzanej, Andrzeja Szczerbę - projektanta galanterii drzewnej, Annę SteckąArczyńską - etnografkę.

Ze Spółdzielnią ZWW współpracowali wybitni artyści plastycy, którzy odcisnęli trwały ślad na wyrazie artystycznym Spółdzielni. Wśród nich znaleźli się Barbara Gawdzik-Brzozowska (1927-2010) - artystka plastyk, projektantka odzieży, Tadeusz Brzozowski (1918-1987) - artysta plastyk, wybitny malarz polski, realizował w ZWW projekty monumentalnych gobelinów dla Filharmonii Pomorskiej w Bydgoszczy, Ewa Fajkosz (1929-2003) - artystka plastyk, projektantka odzieży i galanterii skórzanej, Grażyna Hase (ur. 1939) - projektantka mody, twórczyni m.in. projektów wykonanych tu kożuchów dla polskiej ekipy sportowców na X Zimowe Igrzyska Olimpijskie w Grenoble w 1968 r., Józef Kulon (1927-1998), projektant mebli, Zofia Zwolińska (1909-1998) - artystka

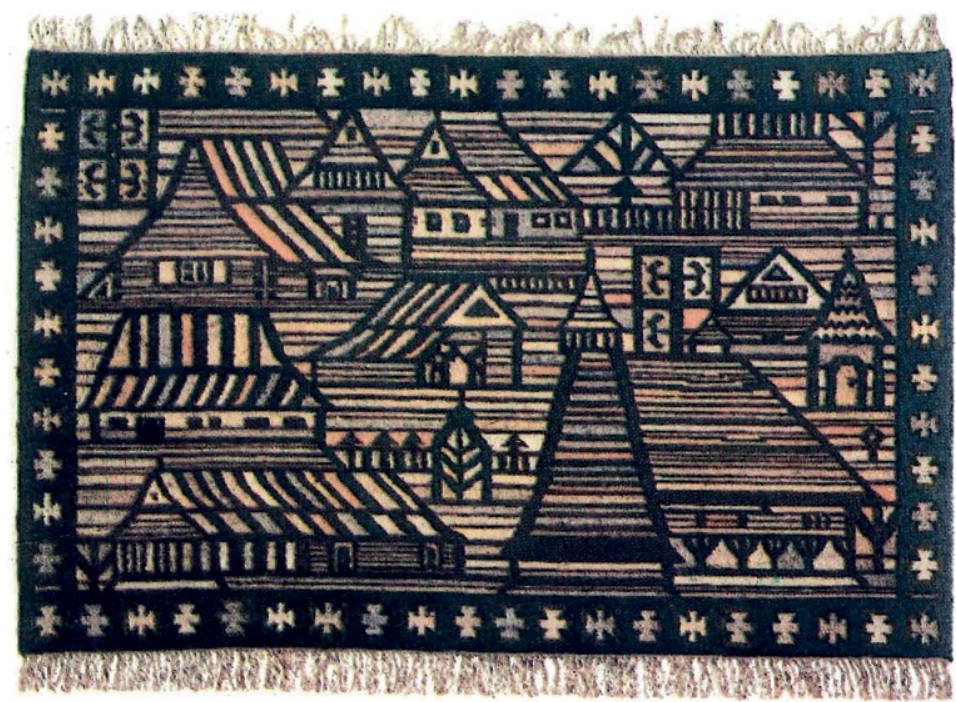

3. Drewniane Podhale, kilim, proj. A. Lewińska. Fot. Z. Zwolińska, wg: Artyści plastycy-projektanci Zakopiańskich Warsztatów Wzorcowych w XXX-lecie działalności, [katalog wystawy], Nowy Targ 1977. fotografik, Władysław Werner (zm. 1982) artysta fotografik.

Bogactwo sztuki ludowej reprezentowało w ZWW wielu twórców ludowych. Najliczniejsi działali w Bukowinie Tatrzańskiej, by wymienić tu Józefa Bigosa (1890-1966), Józefa Pitoraka, rodzinę Kuchtów, rodziny Koszarków i Gracjaszów, mistrzów i artystów kaletnictwa.

W Odrowążu Podhalańskim działały rodziny Kulawiaków, tworząc wysoko oceniane wyroby ludwisarskie. Zdolne hafciarki pracowały w Dzianiszu, Kościelisku, Bystrem i innych wsiach podhalańskich, kilimy wytwarzały góralki na całym Podhalu, a także w ośrodku kilimiarskim w Kasinie Wielkiej.

Wieloletnim prezesem Spółdzielni był jeden z jej współzałożycieli, Mieczysław Ciecióra. Funkcję kierownika do spraw nadzoru artystycznego, przez ponad 25 lat, pełnił Tomasz Knast.

Zakopiańskie Warsztaty Wzorcowe były najbardziej znanym ośrodkiem polskiej tkaniny współczesnej. Pracownią tkactwa przez wiele lat kierowała Maria Bujakowa, która wraz z Krystyną SzczepanowskąMilkaszewską (1912-1998) stworzyła oryginalny ośrodek podhalańskiego kilimiarstwa, oparty na tkactwie ludowym, ale wzbogacony współczesną wyobraźnią plastyczną. Tkaniny pochodzące z ośrodków tkackich na Podhalu, tkane przez góralki pod opieką zawodowych plastyków, odznaczały się własnym, niepowtarzalnym charakterem. Podstawowymi surowcami, zgodnie z tradycjami tkactwa ludowego, były ręcznie przędzone grube i surowe wełny oraz len. Były one farbowane we własnym zakresie barwnikami roślinnymi. Warto chyba wspomnieć, że jeden z kilimów wykonanych w ZWW, Drewniane Podhale, autorstwa Aleksandry Lewińskiej, został wykorzystany przez scenografa w filmie amerykańskim reżyserii Sydneya Pollacka Trzy dni Kondora (il. 3-6). 


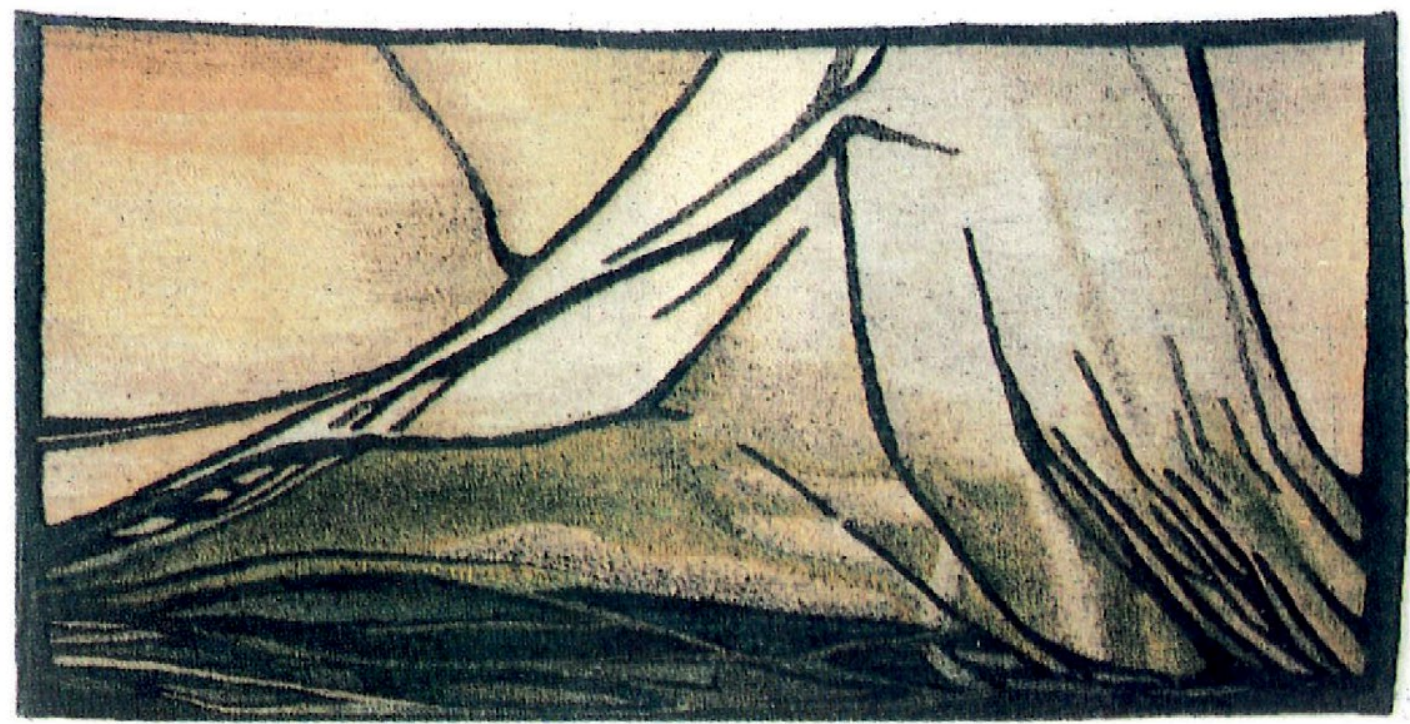

4. Czarny Staw Gąsienicowy, kilim, proj. Helena Sułkowska-Pawlik. Fot. wg Artyści plastycy - projektanci Zakopiańskich Warsztatów Wzorcowych w XXX-lecie działalności, [katalog wystawy], Nowy Targ 1977.

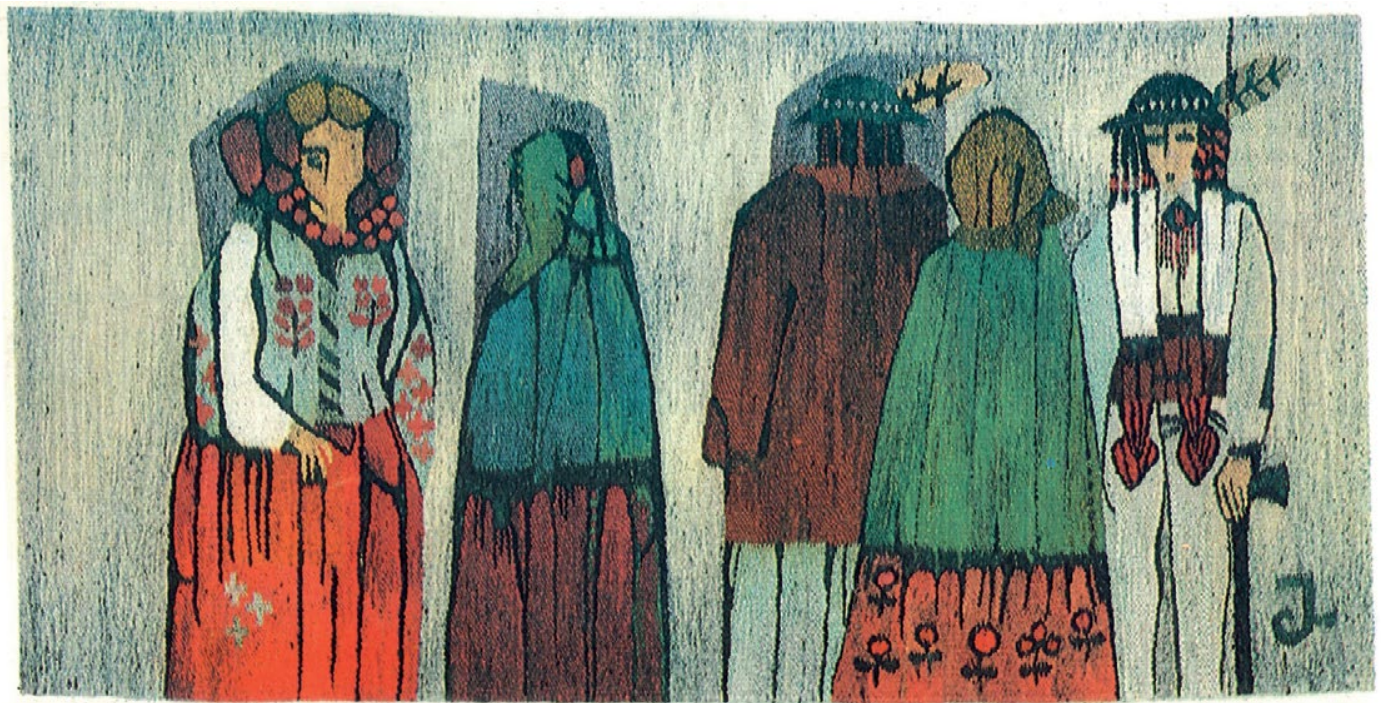

5. Witowianie, kilim, proj. Ewa Januszkowska. Fot. wg J. Knab, Skarbiec podtatrzańskiej sztuki, Warszawa 1977.

Zakopiańskie Warsztaty Wzorcowe znane były także z mebli rustykalnych tworzonych w stylu ludowym, ale nie ludowych. Były one projektowane przez zawodowych plastyków i wytwarzane zarówno seryjnie, jak i rękodzielniczo. Głównym projektantem najbardziej znanych mebli zakopiańskich był Józef Kulon, wybitny artysta, syn góralski spod Zakopanego, wychowanek szkoły Antoniego Kenara, absolwent Krakowskiej Akademii Sztuk Pięknych. To właśnie w Zakopanem zrodziła się idea tworzenia pięknych, oryginalnych mebli, ponieważ „tu, jak nigdzie indziej, ludzie czują i rozumieją drewno, a miłość do tego surowca, a także umiejętność posługiwania się nim dla wydobycia zeń najcenniejszych form, każdy góral ma we krwi"13.

W Zakopiańskich Warsztatach Wzorcowych tworzono też oryginalną galanterię skórzaną - albumy sztancowane lub zdobione metalowymi ornamentami, mosiężnymi rozetkami, paski, portfele, torby

13 T. Kuczyńska, Pamiątka z Polski. Szkice o współczesnej polskiej sztuce użytkowej i ludowej, Warszawa 1978, s. 83. 


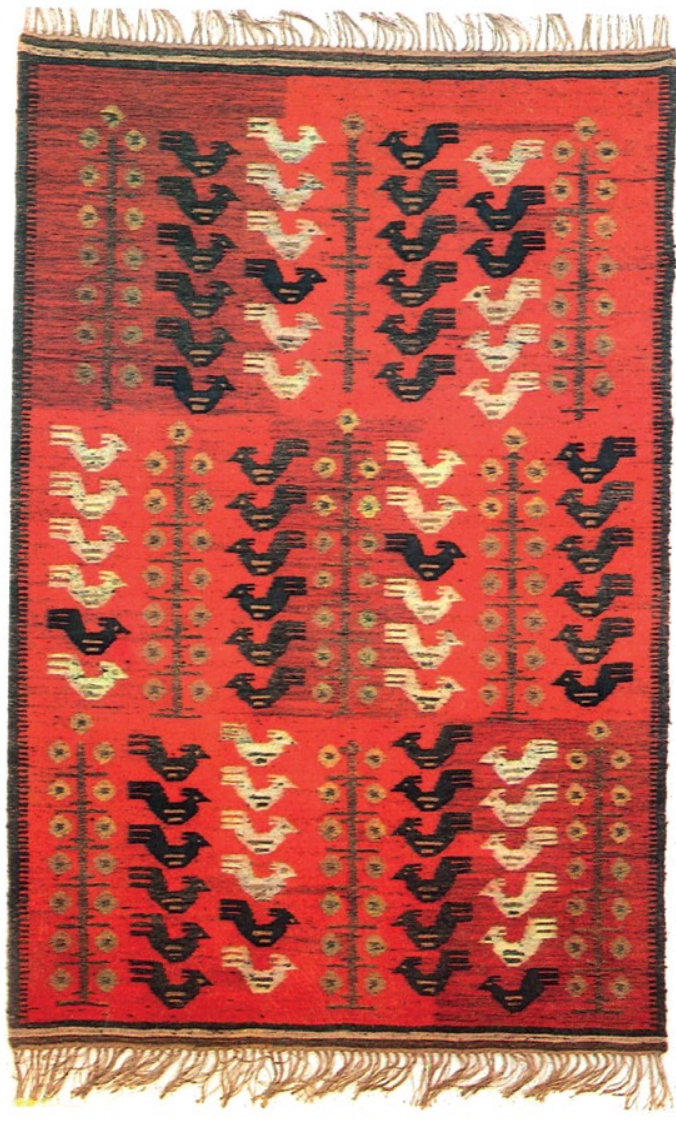

„zakopiańskie” na pasku, z góralskim ornamentem tłoczonym lub nabijanym metalowymi ćwiekami, z ozdobnymi "góralskimi” klamrami, kierpce, opaski, czyli pasy juhaskie, wreszcie bogato zdobione pasy bacowskie. Ważnym działem produkcji była też galanteria drzewna; tworzono kasety, misy, talerze, półeczki - rzeźbione, inkrustowane, wypalane (il. 7).

Bardzo atrakcyjną produkcją mógł poszczycić się dział kuśnierski. Wykonywał on garbowanie i farbowanie skór, produkował haftowane kożuchy regionalne lub będące adaptacją regionalnych wzorów, rękawiczki, pantofle, futrzane narzuty. To tu właśnie w 1968 r. wykonano wspomniane już kożuszki dla narciarskiej reprezentacji olimpijskiej w Grenoble. Kożuszki te weszły potem do normalnej produkcji i były obiektem zachwytu wielu klientów (il. 8).

Doskonałą bazę dla Spółdzielni stanowiły trzy średnie szkoły artystyczne, działające w Zakopanem. Technikum Budowlane im. Władysława Matlakowskiego kształciło stolarzy i cieśli. Liceum Sztuk Plastycznych
6. Ciąg słonek, kilim, proj. Maria Bujak. Fot. wg J. Knab, Skarbiec podtatrzańskiej sztuki, Warszawa 1977.

kształciło rzeźbiarzy, projektantów mebli, lutników. Wreszcie: Technikum Tkactwa Artystycznego im. Heleny Modrzejewskiej przygotowywało do zawodu tkaczki, hafciarki, krawcowe. Współpraca między Spółdzielnią a szkołami była bardzo istotna dla obu stron - polegała na zatrudnianiu absolwentów, udzielaniu szkołom pomocy materialnej, kupowaniu prac.

\section{DZIALALNOŚĆ SOCJALNO- BYTOWA I KULTURALNO- OŚWIATOWA ZWW}

Prócz podstawowych zadań statutowych Spółdzielnia prowadziła dla swoich członków, pracowników i ich rodzin bogatą działalność socjalno-bytową i kulturalno-oświatową. Obejmowała ona nie tylko Podhale, ale sięgała aż poza Gorce, do Kasiny Wielkiej w Limanowskiem. W dziedzinie socjalno-bytowej było to udzielanie nieoprocentowanych, rozłożonych na 36 rat pożyczek budowlanych (maksymalnie ok. 10 miesięcznych pensji), udzielanie nieoprocentowanych pożyczek z Kasy Wzajemnej Pomocy (do wysokości 1 pensji), udzielanie zapomóg losowych, przydzielanie wczasów w dwóch własnych, czteroosobowych domkach w Popławach koło Pułtuska nad Narwią, przydzielanie wczasów w innych ośrodkach Cepelii, refundacja kosztów „wczasów pod gruszą" i inne formy wypoczynku, opłacanie

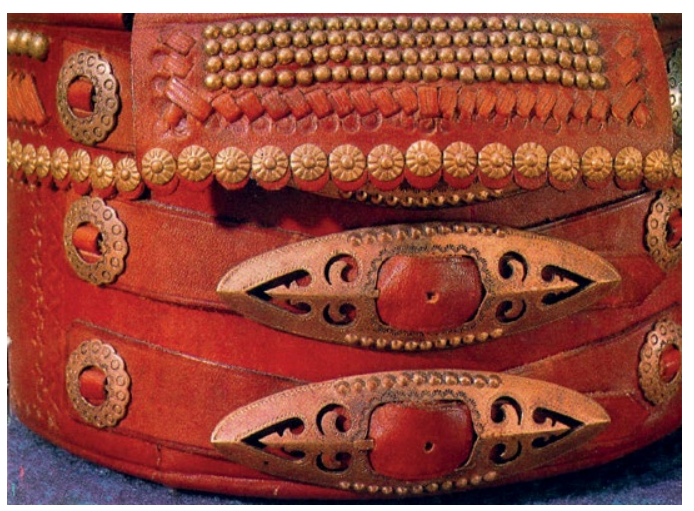

7. Pas bacowski. Fot. wg J. Knab, Skarbiec podtatrzańskiej sztuki, Warszawa 1977. 
kosztów pobytu na koloniach i obozach dla dzieci, refundacja pobytu i leczenia w sanatoriach i wczasach leczniczych, objęcie pracowników Spółdzielni i chałupników bezpłatną opieką medyczną (w pomieszczeniach Spółdzielni działały gabinety: stomatologiczny, internistyczny i ginekologiczny). $\mathrm{Na}$ terenie Spółdzielni prowadzono sklepik ogólnospożywczy oraz stołówkę pracowniczą, która serwowała śniadania i dania barowe. Dla wielu pracowników istotne było, że mogli oni kupić po niskich cenach odpady drzewne i trociny.

Działalność kulturalna i oświatowa to przede wszystkim prowadzenie zespołów regionalnych. Przy ZWW powstały i działały trzy zespoły regionalne: im. Klimka Bachledy, „Holny” i „Zagórzanie”. Zespoły te były laureatami wielu nagród na konkursach krajowych i zagranicznych, w tym kilkakrotnie „Złotej Ciupagi" przyznawanej na Międzynarodowym Festiwalu Folkloru Ziem Górskich w Zakopanem oraz nagrody im. Oskara Kolberga w latach 1976 i 1985. Spółdzielnia opłacała instruktorów, kupowała stroje i instrumenty, finansowała zagraniczne wyjazdy zespołów. W Spółdzielni działała biblioteka, z zatrudnioną na etacie bibliotekarką, organizowano spotkania $\mathrm{z}$ pisarzami oraz $\mathrm{z}$ artystami scen i filmu, rozprowadzano, według zapotrzebowania, bilety na imprezy teatralne i rozrywkowe w mieście. Organizowano wycieczki krajoznawcze po Polsce (m.in. do Warszawy, Trójmiasta i w Bieszczady), imprezy z okazji Dnia Kobiet i Dnia Dziecka. Spółdzielnia utrzymywała drużyny piłki nożnej i piłki siatkowej, działała wypożyczalnia sprzętu turystyczno-wypoczynkowego. Działalność kulturalno-oświatową i socjalno-bytową prowadzono w oparciu o roczne preliminarze uwzględniające potrzeby pracowników ${ }^{14}$.

14 Informacje na podstawie rozmowy z T. Knastem $w \mathrm{dn}$. 3 VI $2020 \mathrm{r}$.

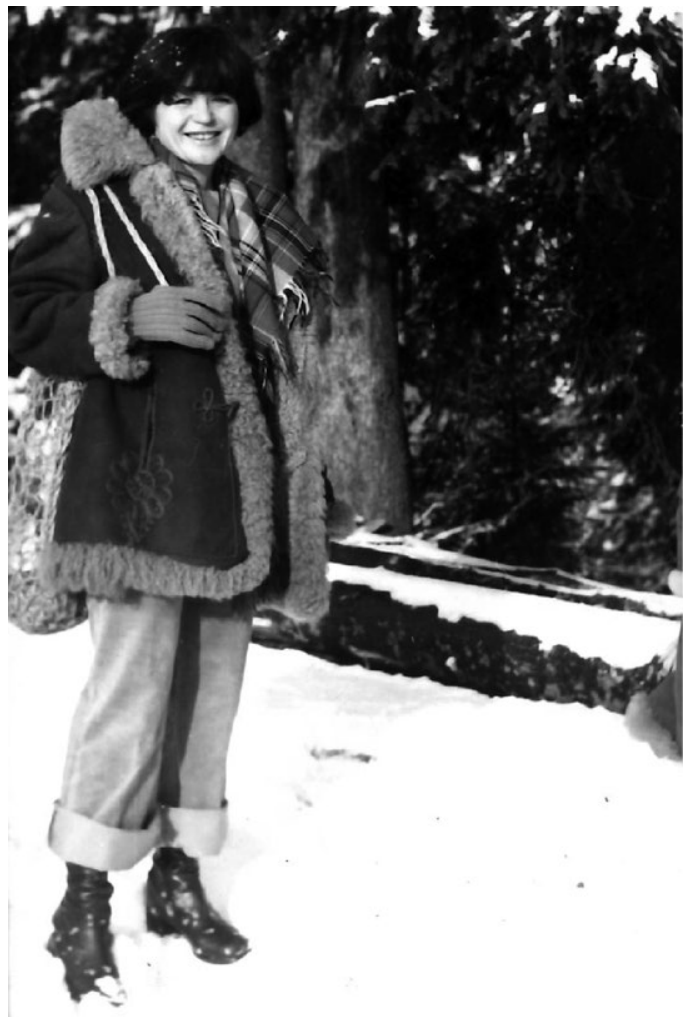

8. Kożuch zaprojektowany i wykonany w ZWW dla polskiej ekipy na X Zimowe Igrzyska Olimpijskie w Grenoble w 1968 r. Fot. archiwum prywatne

\section{ZAKOŃCZENIE DZIAtALNOŚCI}

Rozwój Spółdzielni ZWW trwał nieprzerwanie do końca lat 80. XX w. W latach 90. następował stopniowy regres ekonomiczno-gospodarczy. W 1990 r. Spółdzielnia zatrudniała 264 pracowników w zakładach zwartych, w tym w administracji i handlu oraz 452 chałupników. Natomiast w 2000 r. przy produkcji zatrudnionych było już tylko 79 osób, w administracji i handlu 36, oraz 16 pracowników przy produkcji nakładczej. Bardzo kiedyś rozbudowana lokalna działalność chałupnicza została zastąpiona skupem wyrobów od indywidualnych wytwórców ${ }^{15}$. W dalszym ciągu Spółdzielnia sprzedawała za granicę znaczną część wytwórczości, mimo wahań kursów walut, powodujących problemy z opłacalnością. Sprzedawano głównie do Stanów Zjednoczonych, Niemiec, Anglii i Japonii. Dla przykładu, w 1996 r. Spółdzielnia sprzedała wyroby łącznie za $2,8 \mathrm{mln}$ zł, z tego

15 R. Gmurczyk, dz. cyt., s. 184. 
9. Twórca ludowy Franciszek Kuchta z Bukowiny Tatrzańskiej wykonuje okucia metalowe do wyrobów skórzanych. Fot. W. Werner

za granicę za ok. 1 mln zł, co wówczas stanowiło równowartość ok. 400 tys. USD.

Na przełomie lat 1999/2000 Spółdzielnia w swoim obiekcie przy ul. Szymony zaczęła wynajmować pomieszczenia administracyjno-gospodarcze piętnastu innym użytkownikom. Wkrótce też zaczęła wyprzedawać majątek - m.in. budynek socjalny i działkę z magazynem. W 2002 r. sprzedała wyroby własnej produkcji i ze skupu wartości 2,1 mln zł. Około 50\% sprzedano do krajów Unii Europejskiej i Stanów Zjednoczonych. W kolejnych latach bilans zamykał się stratą. W 2006 r. członków Spółdzielni było już tylko 70. W roku 2007 członkowie ZWW podjęli uchwałę o likwidacji Spółdzielni. W tym samym roku cały majątek Spółdzielni został sprzedany. $\mathrm{Na}$ miejscu budynku Zakopiańskich Warsztatów Wzorcowych powstaje obecnie, jako signum temporis, wielokondygnacyjny apartamentowiec.

Zakopiańskie Warsztaty Wzorcowe pod względem zatrudnienia, wielkości produkcji i eksportu były największym zakładem w gronie ponad 120 spółdzielni cepeliowskich. Ich wkład w kulturę materialną Podhala i Polski jest ogromny. W bardzo licznych domach w Polsce znajdują się hafty, kilimy, skórzane paski z metalowymi klamrami, kasetki drewniane, albumy pochodzące z tych warsztatów. Do dziś w przetworzonej i uproszczonej formie wzory powstałe w ZWW są wykorzystywane przez górali przy produkcji pamiątek z Zakopanego. Jak kiedyś Spółdzielnia korzystała z bogatej tradycji rękodzieła i sztuki ludowej XIX w. i pocz. XX w., tak teraz na jej dorobku bazują współcześni rękodzielnicy i liczni na Podhalu wytwórcy pamiątek (il. 9).

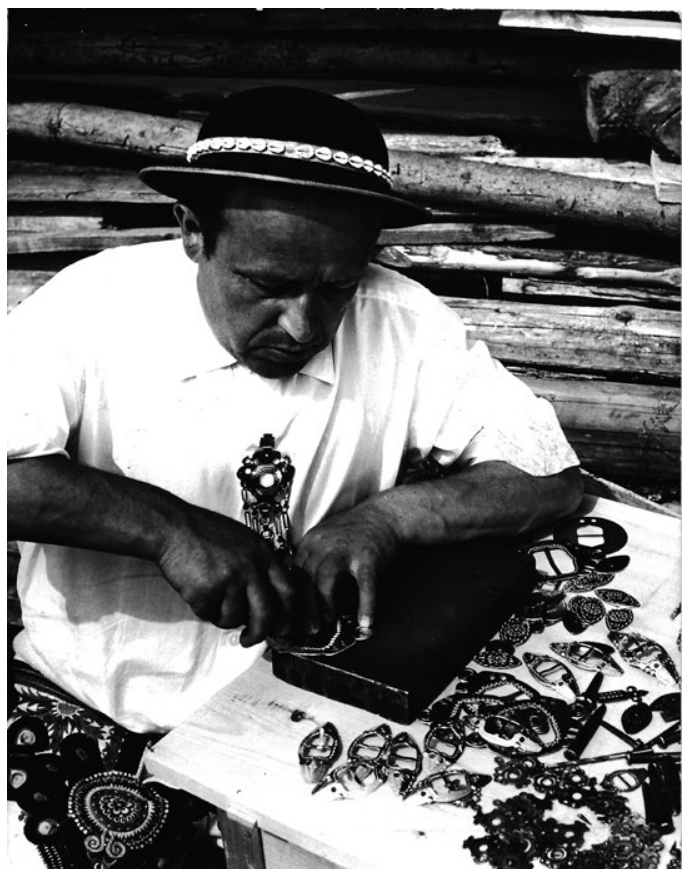

W Spółdzielni Zakopiańskie Warsztaty Wzorcowe rocznie wprowadzano do produkcji ponad 120 nowych wzorów kilimów, gobelinów, haftów, kożuchów, galanterii skórzanej (toreb, pasków), galanterii drzewnej (kaset, talerzy, mebli). Projekty były oceniane i wyceniane według prawa autorskiego przez Centralną Komisję Artystyczną w Warszawie. W latach 8o. Spółdzielnia otrzymała od Cepelii uprawnienia do prowadzenia własnej komisji artystycznej do oceny wzorów przedstawianych przez własnych projektantów i innych podhalańskich twórców spoza ZWW. Wysoki poziom wzornictwa Zakopiańskich Warsztatów Wzorcowych wynikał z jednej strony z dobrze przygotowanych kadr, z drugiej - z przestrzegania żelaznych zasad projektowania, które stanowiły: dobry wzór, używanie naturalnych, ręcznie przygotowywanych surowców, rękodzielnicze wykonanie. To właśnie sprawiało, że zakopiańska Spółdzielnia była tak konkurencyjna wśród ponad stu spółdzielni cepeliowskich i licznych firm państwowych. 
STRESZCZENIE

ZAKOPIAŃSKIE WARSZTATY WZORCOWE

- DZIAŁALNOŚĆ WYTWÓRCZA

PIERWSZEJ NA PODHALU SPÓtDZIELNI ARTYSTYCZNEJ

Komunikat dotyczy dziejów Zakopiańskich Warsztatów Wzorcowych Cepelia. Opisuje początki działalności spółdzielni, okres jej funkcjonowania i zakończenie działalności. Poruszone zostały także zagadnienia dotyczące systemu pracy wewnątrz spółdzielni, zaprezentowane wiodące produkty oraz wspomniane nazwiska wybitnych twórców i artystów współpracujących ze Spółdzielnią.

\section{SŁOWA KLUCZOWE}

Zakopiańskie Warsztaty Wzorcowe, Cepelia, Zakopane, spółdzielnia, rękodzieło, wyroby regionalne, pamiątkarstwo, wzornictwo ludowe, ludowość, tradycyjne wyroby

\section{BIBLIOGRAFIA}

\section{Archiwalia}

Archiwa prywatne dawnych pracowników ZWW.

Zakopiańskie Warsztaty Wzorcowe Spółdzielni Pracy Rękodzieła Ludowego i Artystycznego w Zakopanem, Arch. Narodowe w Krakowie, Ekspozytura Spytkowice (nr zespołu 32/750) oraz Oddział w Nowym Sączu (nr zespołu 31/1121).

\section{Opracowania}

Artyści plastycy-projektanci Zakopiańskich Warsztatów Wzorcowych w XXX-lecie

\section{SUMMARY}

THE GENERATIVE ACTIVITY OF ZAKOPIAŃSKIE WARSZTATY WZORCOWE

- THE FIRST ART AND REGIONAL COOPERATIVE ON PODHALE

The article concerns the Zakopianskie Warsztaty Wzorcowe Cepelia, describing the beginning of its activity, its functioning and the end of its activity. The article also deals with issues such as the work system of the cooperative, the description of the flagship products created in the Cepelia and the names of famous artists cooperating with the Zakopianskie Warsztaty Wzorcowe Cepelia.

\section{KEY WORDS}

Zakopiańskie Warsztaty Wzorcowe, Cepelia, Zakopane, cooperative, regional handicraft, folk design, folksiness, traditional products

działalności [katalog wystawy], Nowy Targ 1977.

25-lecie Zakopiańskich Warsztatów Wzorcowych, [katalog wystawy], Zakopane 1973.

Gmurczyk Roman, Organizacja cepeliowska w latach 1949-2014. Fakty i ludzie, Warszawa 2014.

Kuczyńska Teresa, Pamiątka z Polski. Szkice o współczesnej polskiej sztuce użytkowej i ludowej, Warszawa 1978.

Sarkowicz Magdalena, Zakopiańskie Warsztaty Wzorcowe, „Podtatrze”, 1978, zima, s. 18-23.

Zborowski Juliusz, Pisma podhalańskie, t. 2, Kraków 1972. 